in vivo $34: 1915-1920(2020)$

doi:10.21873/invivo.11988

\title{
Treatment Outcome of Resection of Disseminated Peritoneal Metastases from Colorectal Cancer
}

\author{
GAKU OHIRA, HIDEAKI MIYAUCHI, KOICHI HAYANO, MICHIHIRO MARUYAMA, \\ SHUNSUKE IMANISHI, TORU TOCHIGI, TETSURO MARUYAMA, \\ TOSHIHARU HANAOKA, KOICHIRO OKADA and HISAHIRO MATSUBARA
}

\author{
Department of Frontier Surgery, Chiba University Graduate School of Medicine, Chiba, Japan
}

\begin{abstract}
Aim: To show the treatment outcomes of disseminated nodule resection for peritoneal metastasis of colorectal cancer and describe the details of cured cases. Patients and Methods: From January 2001 to December 2016, patients who underwent disseminated nodule resection of colorectal adenocarcinoma with no macroscopic residual tumor in our institution were retrospectively analyzed for clinicopathological factors associated with prognosis. Results: Forty-one cases were included in this study. The 3year relapse-free survival was $12.5 \%$, and the 5-year overall survival was $38.4 \%$. In a multivariate analysis, lack of postoperative adjuvant chemotherapy and pre-operative carbohydrate antigen 19-9 over 100 IU/l were extracted as independent factors associated with short relapse-free survival, respectively. Among 41 cases, 32 were followed-up 5 years after surgery and five (15.6\%) survived without relapse and were regarded as 'cured'. Conclusion: More than a few cases of colorectal peritoneal metastasis, which is thought to be difficult to cure, were cured by resection of disseminated nodules without resorting to highly invasive treatment.
\end{abstract}

Peritoneal metastasis (PM) of colorectal cancer is regarded as an incurable condition compared with that to the liver or lung, due to its unfavorable treatment outcome (1). Recently, cytoreductive surgery (CRS) and perioperative intraperitoneal chemotherapy (POIC), including hyperthermic intraperitoneal chemotherapy, have been reported to be associated

This article is freely accessible online.

Correspondence to: Gaku Ohira, Department of Frontier Surgery, Chiba University Graduate School of Medicine, 1-8-1 Inohana, Chuuou-ku, Chiba 260-8670, Japan. Tel.: +81 432602110, Fax: +81 432602113, e-mail: Ohira@faculty.chiba-u.jp

Key Words: Colorectal cancer, peritoneal metastasis, nodule resection. with a good treatment outcome for PM of colorectal cancer, mostly by Sugarbaker et al. (2, 3). Such advancements have suggested that a cure can now be achieved. However, POIC is not covered by the national insurance system of Japan and has been performed at only a few institutions. Furthermore, these treatments were reported to cause severe adverse events, therefore the potential pool for such therapy may be limited $(4,5)$.

Several reports have described a potential benefit of resection of disseminated PM of colorectal cancer (6-8). Although nodule resection itself is not a curative treatment for PM in theory, the outcome of this treatment has been dramatically improved by combining it with systemic chemotherapy, in light of recent advances in systemic chemotherapy.

We herein report the treatment outcomes of nodule resection for PM of colorectal cancer and describe the details of cured cases.

\section{Patients and Methods}

Patients. From January 2001 to December 2016, patients who underwent resection of visible disseminated nodules leading to no macroscopic residual tumor for PM of pathologically proven colorectal adenocarcinoma at Chiba University Hospital, Chiba, Japan were included in this study. This study was approved by the Institutional Review Board of Chiba University School of Medicine and was registered in UMIN Clinical Trials Registry (UMIN000035807).

Study items. The details of patient age, sex, side of the primary site, timing of PM (synchronous or metachronous), pathological type, peritoneal carcinoma index (PCI), metastasis other than PM, tumor marker [carcinoembryonic antigen (CEA) and carbohydrate antigen 19-9 (CA19-9)] before surgery, number of resections, intra-operative lavage cytology, and peri-operative systemic chemotherapy were investigated. The rates of relapse-free survival (RFS) and overall survival (OS) from the time of resection were calculated by the Kaplan-Meier method, and the factors affecting RFS and OS were analyzed by univariate and multivariate analyses.

Patients who survived for more than 5 years without any relapse of colorectal cancer after surgery were defined as 'cured cases', and the details of these cases were studied. 
Table I. Background characteristics of 41 cases of peritoneal metastases (PM) from colorectal cancer.

\begin{tabular}{|c|c|c|}
\hline & & Value \\
\hline Age, years & Median (range) & $66(30-87)$ \\
\hline \multirow[t]{2}{*}{ Gender, n (\%) } & Male & $17(41.5 \%)$ \\
\hline & Female & $24(58.5 \%)$ \\
\hline \multirow[t]{2}{*}{ Site of primary tumor, $\mathrm{n}(\%)$} & Right side & $19(46.3 \%)$ \\
\hline & Left side & $22(53.7 \%)$ \\
\hline \multirow[t]{2}{*}{ Histology, n (\%) } & Well/moderate & $34(82.9 \%)$ \\
\hline & Poor/mucinous & $7(17.1 \%)$ \\
\hline \multirow[t]{2}{*}{ Degree of PM, n (\%) } & $\mathrm{P} 1$ & $13(31.7 \%)$ \\
\hline & $\mathrm{P} 2$ & $28(68.3 \%)$ \\
\hline \multirow[t]{3}{*}{ PCI, n (\%) } & $>5$ & $7(17.1 \%)$ \\
\hline & $\leq 5$ & $30(73.2 \%)$ \\
\hline & Unknown & $4(\%)$ \\
\hline \multirow{2}{*}{$\begin{array}{l}\text { Pre-operative serum } \\
\text { CEA, n }(\%)\end{array}$} & $>10 \mathrm{ng} / \mathrm{ml}$ & $16(39.0 \%)$ \\
\hline & $\leq 10 \mathrm{ng} / \mathrm{ml}$ & $25(61.0 \%)$ \\
\hline \multirow{3}{*}{$\begin{array}{l}\text { Pre-operative serum } \\
\text { CA19-9, n }(\%)\end{array}$} & $>100 \mathrm{U} / \mathrm{ml}$ & $10(24.4 \%)$ \\
\hline & $\geq 100 \mathrm{U} / \mathrm{ml}$ & $30(73.2 \%)$ \\
\hline & NA & $1(\%)$ \\
\hline \multirow[t]{2}{*}{ Diagnostic interval } & Synchronous & $20(48.8 \%)$ \\
\hline & Metachronous & $21(51.2 \%)$ \\
\hline \multirow{2}{*}{$\begin{array}{l}\text { Distant metastases other } \\
\text { than PM, } \mathrm{n}(\%)\end{array}$} & Yes & $14(34.1 \%)$ \\
\hline & None & $27(65.9 \%)$ \\
\hline \multirow[t]{4}{*}{ Number of resections, $\mathrm{n}(\%)$} & 1 & $28(68.3 \%)$ \\
\hline & 2 & $9(22.0 \%)$ \\
\hline & 3 & $3(7.3 \%)$ \\
\hline & 4 & $1(2.4 \%)$ \\
\hline \multirow{3}{*}{$\begin{array}{l}\text { Intraperitoneal lavage } \\
\text { cytology, n (\%) }\end{array}$} & Positive & $12(29.3 \%)$ \\
\hline & Negative & $16(39.0 \%)$ \\
\hline & Not done & $13(31.7 \%)$ \\
\hline \multirow{2}{*}{$\begin{array}{l}\text { Neo-adjuvant chemotherapy, } \\
\mathrm{n}(\%)\end{array}$} & Yes & $9(22.0 \%)$ \\
\hline & No & $32(78.0 \%)$ \\
\hline \multirow{2}{*}{$\begin{array}{l}\text { Postoperative chemotherapy, } \\
\mathrm{n}(\%)\end{array}$} & Yes & $24(58.5 \%)$ \\
\hline & No & $17(41.5 \%)$ \\
\hline
\end{tabular}

PCI: Peritoneal carcinoma index; CEA: carcinoembryonic antigen; CA19-9: carbohydrate antigen 19-9.

Statistical analyses. The log-rank test was used in the univariate analysis, and Cox's proportional hazard model was used in the multivariate analysis. A $p$-value less than 0.05 was regarded as significant. Data were statistically analyzed using JMP software, version 12 (SAS Institute Inc., Cary, NC, USA).

\section{Results}

Forty-one cases were retrospectively identified and included in this study. The patients' background characteristics are shown in Table I. There were 20 case of synchronous PM and 21 cases of metachronous PM. Over half of the cases underwent single surgery, while 13 underwent multiple resection. Intraoperative lavage cytology was performed in 28 cases $(68.3 \%)$, and 16 cases were negative for cytology despite PM.

The survival curves of the RFS and OS are shown in Figure 1. The median observation period was 27.8 months.
Table II. Univariate and multivariate analysis of the relapse-free survival of 41 cases of peritoneal metastasis (PM) from colorectal cancer.

\begin{tabular}{|c|c|c|c|c|}
\hline & \multirow[b]{2}{*}{$\begin{array}{l}\text { No. of } \\
\text { patients }\end{array}$} & \multirow[b]{2}{*}{$\begin{array}{c}\text { Median-RFS } \\
\text { (months) }\end{array}$} & \multicolumn{2}{|c|}{$p$-Value } \\
\hline & & & $\begin{array}{l}\text { Univariate } \\
\text { analysis }\end{array}$ & $\begin{array}{c}\text { Multivariate } \\
\text { analysis }\end{array}$ \\
\hline \multicolumn{5}{|l|}{ Age } \\
\hline$>70$ Years & 27 & 5.4 & 0.4957 & \\
\hline$\leq 70$ Years & 14 & 11 & & \\
\hline \multicolumn{5}{|l|}{ Gender } \\
\hline Male & 17 & 7.45 & 0.1561 & 0.2897 \\
\hline Female & 24 & 12.6 & & \\
\hline \multicolumn{5}{|l|}{ Site of primary tumor } \\
\hline Right side & 19 & 10.1 & 0.8303 & \\
\hline Left side & 22 & 12.1 & & \\
\hline \multicolumn{5}{|l|}{ Histology } \\
\hline Well/moderately & 34 & 10.9 & 0.2891 & \\
\hline Poorly/mucinous & 7 & 11 & & \\
\hline \multicolumn{5}{|l|}{ Degree of PM } \\
\hline $\mathrm{P} 1$ & 13 & 10.9 & 0.5862 & \\
\hline $\mathrm{P} 2$ & 28 & 10.9 & & \\
\hline \multicolumn{5}{|l|}{ PCI } \\
\hline$>5$ & 7 & 10.9 & 0.914 & \\
\hline$\leq 5$ & 30 & 13.4 & & \\
\hline \multicolumn{5}{|l|}{ Pre-operative CEA } \\
\hline$>10 \mathrm{ng} / \mathrm{ml}$ & 16 & 10.1 & 0.7934 & \\
\hline$\leq 10 \mathrm{ng} / \mathrm{ml}$ & 25 & 11.35 & & \\
\hline \multicolumn{5}{|c|}{ Pre-operative CA19-9 } \\
\hline$>100 \mathrm{U} / \mathrm{ml}$ & 10 & 5.55 & 0.0065 & 0.1519 \\
\hline$\leq 100 \mathrm{U} / \mathrm{ml}$ & 30 & 13.2 & & \\
\hline \multicolumn{5}{|l|}{ Diagnostic interval } \\
\hline Synchronous & 20 & 10.9 & 0.3872 & \\
\hline Metachronous & 21 & 10.9 & & \\
\hline \multicolumn{5}{|l|}{$\begin{array}{l}\text { Distant metastases } \\
\text { other than PM }\end{array}$} \\
\hline Yes & 14 & 5.85 & 0.8158 & \\
\hline No & 27 & 10.95 & & \\
\hline \multirow{2}{*}{\multicolumn{5}{|c|}{$\begin{array}{l}\text { Intraperitoneal } \\
\text { lavage cytology }\end{array}$}} \\
\hline & & & & \\
\hline Positive & 12 & 8.6 & 0.1136 & 0.1434 \\
\hline Negative & 16 & 15.7 & & \\
\hline \multicolumn{5}{|l|}{$\begin{array}{l}\text { Neo-adjuvant } \\
\text { chemotherapy }\end{array}$} \\
\hline Yes & 9 & 9.1 & 0.419 & \\
\hline No & 32 & 10.9 & & \\
\hline \multicolumn{5}{|l|}{$\begin{array}{l}\text { Postoperative } \\
\text { chemotherapy }\end{array}$} \\
\hline Yes & 24 & 13.45 & 0.0101 & 0.0259 \\
\hline No & 17 & 5.1 & & \\
\hline
\end{tabular}

PCI: Peritoneal carcinoma index; CEA: carcinoembryonic antigen; CA19-9: carbohydrate antigen 19-9. Bold values show significance.

The median RFS of all cases was 10.9 months, and the 3year RFS was as low as $12.5 \%$. The median OS was 38.7 months, and 5-year OS was $38.4 \%$.

Results of the univariate and multivariate analyses of the RFS are shown in Table II. Those patients without post- 

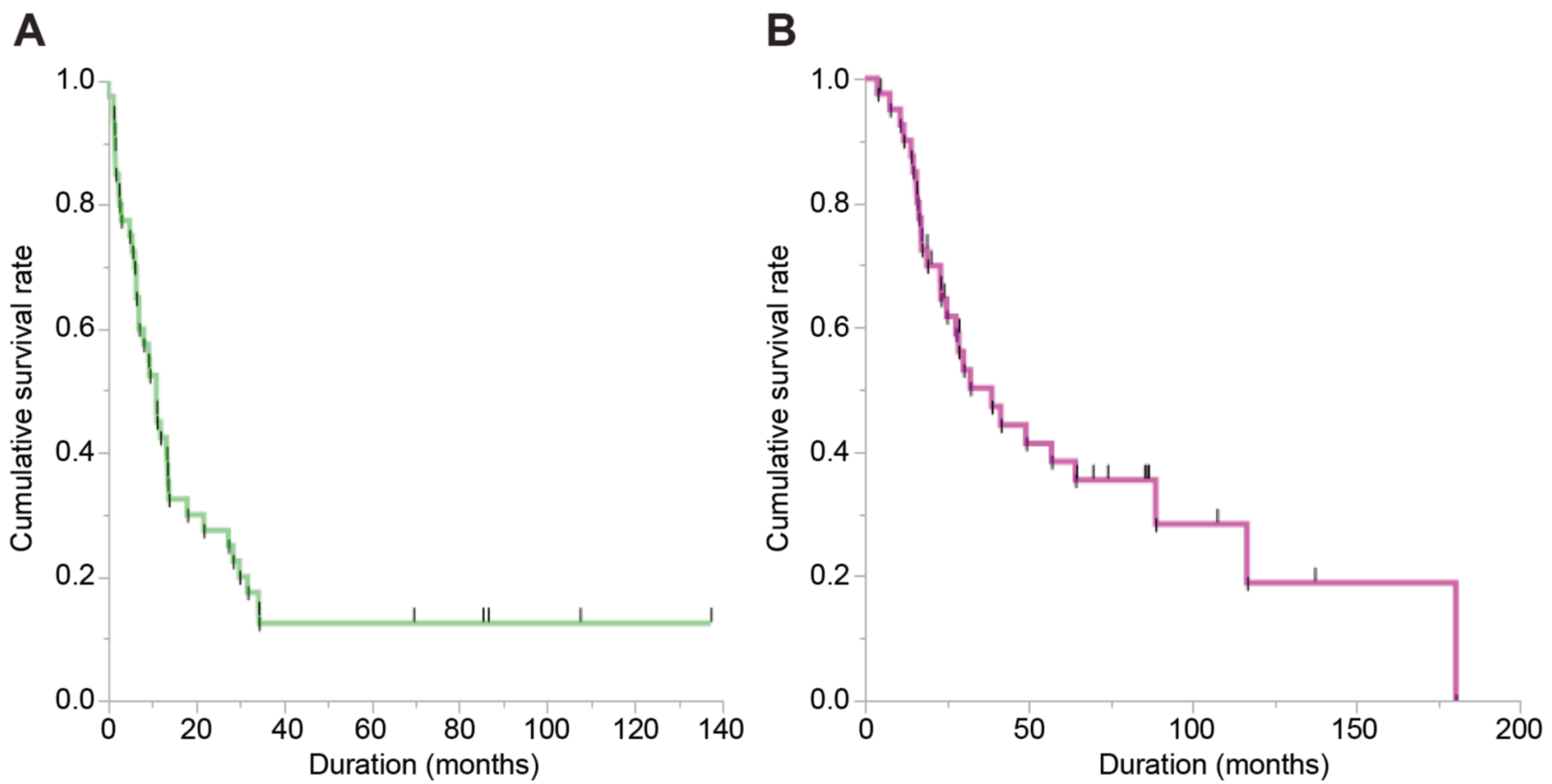

Figure 1. Relapse-free survival curve (A) and overall survival curve (B) for 41 patients who underwent resection of disseminated nodule of colorectal peritoneal metastases with no macroscopic residual tumor.

operative adjuvant chemotherapy (POAC) or CA19-9 over $100 \mathrm{IU} / 1$ had a significant shorter RFS in the univariate analysis than others. A multivariate analysis was performed for factors with $p \leq 0.2$ in the univariate analysis, and no POAC was extracted as an independent factor associated with a short RFS (hazard ratio $=3.22, p=0.0259$ ). Regarding OS, those without POAC, CA19-9 over 100 IU/1, or poorly differentiated or mucinous carcinoma had a significantly poor prognosis in the univariate analysis. A multivariate analysis was performed for factors with $p<0.1$ in the univariate analysis, and only pre-operative CA19-9 over 100 IU/1 was extracted as an independent factor associated with a poor prognosis (hazard ratio $=3.02, p=0.0254$ ) (Table III).

Among 41 cases, 32 were followed-up 5 years after surgery. Of those 32 cases, five (15.6\%) survived without relapse for more than 5 years and were regarded as 'cured'. The details of these cases are shown in Table IV. Four cases had metachronous PM, and all cases had well- or moderately differentiated adenocarcinoma. All five cases had a PCI of 4 or less. Only one case had distant metastasis without PM (port site recurrence). Four cases underwent POAC, and two of them also received neo-adjuvant chemotherapy (NAC). Four cases were negative for intra-operative lavage cytology.

\section{Discussion}

PM is regarded as the worst form distant metastasis of colorectal cancer, and patients with PM are classified as stage IVC in the eighth edition of the TNM classification (9). CRS and POIC for PM of colorectal cancer are reportedly associated with an excellent treatment outcome (2) but the severe surgical stress and high post-operative complication rate have kept them from becoming standard therapies $(4,5)$. Some reports of resection for disseminated PM of colorectal cancer have noted improved treatment outcomes when combined with advanced systemic chemotherapy (6-8). Although the 3-year RFS in this study was relatively low at $12.5 \%$, several cases were able to tolerate nodule re-resection (13 cases, $31.7 \%$ ), and the 5-year OS was comparable to the OS after hepatectomy for hepatic metastasis of colorectal cancer reported in the literature.

In this study, patients who achieved a 5-year RFS were defined as cured, and $15.6 \%$ of cases survived for more than 5 years after nodule resection were cured. Goere et al. reported that $16 \%$ of cases treated with CRS and POIC were cured (10), which is comparable to our findings. However, the study of Goere et al. included cases with relatively higher PCI scores (up to 36), so nodule resection cannot be said to be equivalent to CRS and POIC. The present findings indicate that there are some cases of reportedly difficult-tocure PM of colorectal cancer in which a cure can be achieved by nodule resection.

In general, metachronous metastasis has milder malignancy and a better prognosis than synchronous metastasis $(11,12)$. However, for colorectal cancer, metachronous PM has largely been reported to have equivalent malignancy to synchronous 
Table III. Univariate and multivariate analysis of the mean overall survival (MST) of 41 cases of peritoneal metastasis (PM) from colorectal cancer.

\begin{tabular}{|c|c|c|c|c|}
\hline & \multirow[b]{2}{*}{$\begin{array}{l}\text { No. of } \\
\text { patients }\end{array}$} & \multirow[b]{2}{*}{$\begin{array}{c}\text { MST } \\
\text { (months) }\end{array}$} & \multicolumn{2}{|c|}{$p$-Value } \\
\hline & & & $\begin{array}{l}\text { Univariate } \\
\text { analysis }\end{array}$ & $\begin{array}{c}\text { Univariate } \\
\text { analysis }\end{array}$ \\
\hline \multicolumn{5}{|l|}{ Age } \\
\hline$>70$ Years & 27 & 28.6 & 0.1792 & \\
\hline$\leq 70$ Years & 14 & 49.2 & & \\
\hline \multicolumn{5}{|l|}{ Gender } \\
\hline Male & 17 & 25 & 0.3405 & \\
\hline Female & 24 & 41.5 & & \\
\hline \multicolumn{5}{|c|}{ Site of primary tumor } \\
\hline Right side & 19 & 27.8 & 0.0613 & 0.1513 \\
\hline Left side & 22 & 88.8 & & \\
\hline \multicolumn{5}{|l|}{ Histology } \\
\hline Well/moderately & 34 & 41.5 & 0.0196 & 0.0563 \\
\hline Poorly/mucinous & 7 & 23.2 & & \\
\hline \multicolumn{5}{|l|}{ Degree of PM } \\
\hline $\mathrm{P} 1$ & 13 & 23.2 & 0.1601 & \\
\hline $\mathrm{P} 2$ & 28 & 49.2 & & \\
\hline \multicolumn{5}{|l|}{ PCI } \\
\hline$>5$ & 7 & 23.2 & 0.1977 & \\
\hline$\leq 5$ & 30 & 41.5 & & \\
\hline \multicolumn{5}{|l|}{ Pre-operative CEA } \\
\hline$>10 \mathrm{ng} / \mathrm{ml}$ & 16 & 57 & 0.3465 & \\
\hline$\leq 10 \mathrm{ng} / \mathrm{ml}$ & 25 & 30.1 & & \\
\hline \multicolumn{5}{|c|}{ Pre-operative CA19-9 } \\
\hline$>100 \mathrm{U} / \mathrm{ml}$ & 10 & 17.3 & 0.0045 & 0.0254 \\
\hline$\leq 100 \mathrm{U} / \mathrm{ml}$ & 30 & 49.2 & & \\
\hline \multicolumn{5}{|l|}{ Diagnostic interval } \\
\hline Synchronous & 20 & 25 & 0.3872 & \\
\hline Metachronous & 21 & 60.65 & & \\
\hline \multicolumn{5}{|l|}{$\begin{array}{l}\text { Distant metastases } \\
\text { other than PM }\end{array}$} \\
\hline Yes & 14 & 28.6 & 0.9262 & \\
\hline No & 27 & 38.7 & & \\
\hline \multicolumn{5}{|l|}{$\begin{array}{l}\text { Intraperitoneal } \\
\text { lavage cytology }\end{array}$} \\
\hline Positive & 12 & 41.5 & 0.1648 & \\
\hline Negative & 16 & 116.7 & & \\
\hline \multicolumn{5}{|l|}{$\begin{array}{l}\text { Neo-adjuvant } \\
\text { chemotherapy }\end{array}$} \\
\hline Yes & 9 & NA & 0.2305 & \\
\hline No & 32 & 27.8 & & \\
\hline \multicolumn{5}{|l|}{$\begin{array}{l}\text { Postoperative } \\
\text { chemotherapy }\end{array}$} \\
\hline Yes & 24 & 64.3 & 0.0104 & 0.2194 \\
\hline No & 17 & 20 & & \\
\hline
\end{tabular}

PCI: Peritoneal carcinoma index; CEA: carcinoembryonic antigen; CA19-9: carbohydrate antigen 19-9. Bold values show significance.

PM (13-15). Synchronous PM is often detected incidentally during an operation. In contrast, metachronous PM can be difficult to detect in the early stage and therefore tends to be diagnosed late, which may be one reason for the unfavorable treatment outcomes associated with metachronous PM. However, no significant differences between metachronous and synchronous PM were noted in the RFS or OS in the present study, although the median OS of those with metachronous PM was much longer than that of synchronous PM (60.7 vs. 25 months). Among the five cured patients, four suffered from metachronous PM, and the above results indicate that resectable metachronous PM has a better prognosis than synchronous PM.

In the present study, intraoperative lavage cytology was performed in $68.3 \%$ of cases. Surprisingly, over half of the cases that underwent cytology showed negative findings for cancer cells despite PM. However, despite the lack of significance, the median RFS and median OS of cases with negative cytological findings were 15.7 and 116.7 months, respectively. These findings suggested that intraoperative lavage cytology may become a powerful prognostic tool in the future.

High levels of CA19-9 were extracted as an independent prognostic factor in a multivariate analysis, and patients with high levels of CA19-9 had a significantly shorter RFS than those with lower levels according to the univariate analysis in this study. Ihemelandu listed CA19-9 as a significant prognosticator along with the platelet-lymphocyte ratio and Onodera's nutritional index, in patients with PM of colonic cancer (16). Park et al. reported that an elevated CA19-9 level was more closely associated with PM than hepatic metastases and that patients with high levels of CA19-9 tended to develop relapse in the peritoneum (17). Our own results were consistent with these, suggesting that patients with high levels of CA19-9 with colorectal PM should be carefully considered for surgery.

In the present study, lack of POAC was extracted as an independent factor for early relapse in a multivariate analysis. Four out of the five patients who achieved a cure in the present study received POAC, and the remaining patient without POAC had received systemic chemotherapy in the past. These results suggest the importance of systemic chemotherapy in the surgical treatment of colorectal PM. In an effort to achieve a better outcome, we have introduced NAC for extremely advanced colorectal cancer (18). Nine patients in the present study underwent NAC, but no significant difference was observed in the RFS or OS between the NAC cases and other cases probably due to the small number of cases. Further studies will be needed to clarify the efficacy of NAC.

Several limitations associated with the present study warrant mention. Firstly, this was a retrospective study of cases in which it was possible to resect peritoneal metastases macroscopically. Cases with severe PM that could not be resected without CRS were excluded. Secondly, this study was performed at a single institution with a small number of cases.

In conclusion, even when targeting mild cases of PM from colorectal cancer, relatively good results were obtained with 
Ohira et al: Resection for Colorectal Peritoneal Metastases

Table IV. Details of five cases survived without relapse for more than 5 years, which were regarded as 'cured'.

\begin{tabular}{|c|c|c|c|c|c|c|c|c|c|c|c|}
\hline $\begin{array}{l}\text { Age, } \\
\text { years/ } \\
\text { gender }\end{array}$ & $\begin{array}{l}\text { Timing } \\
\text { of PM }\end{array}$ & $\begin{array}{l}\text { Primary } \\
\text { site }\end{array}$ & $\begin{array}{l}\text { Time from } \\
\text { primary } \\
\text { resection } \\
\text { (months) }\end{array}$ & $\begin{array}{l}\text { Pathological } \\
\text { type }\end{array}$ & $\begin{array}{l}\text { CEA } \\
(\mathrm{ng} / \mathrm{ml})\end{array}$ & $\begin{array}{c}\text { CA 19-9 } \\
\text { (U/ml) }\end{array}$ & PCI & $\begin{array}{c}\text { Distant } \\
\text { metastases } \\
\text { other than } \\
\text { PM }\end{array}$ & $\begin{array}{l}\text { Lavage } \\
\text { cytology }\end{array}$ & $\begin{array}{c}\text { Surgical } \\
\text { procedure }\end{array}$ & Chemotherapy \\
\hline $75 / \mathrm{F}$ & Metachronous & Rectum & 14.4 & Well & 1.4 & 1.8 & 1 & None & Negative & $\mathrm{TE}$ & Pre/post \\
\hline $60 / \mathrm{F}$ & Metachronous & $\begin{array}{l}\text { Ascending } \\
\text { colon }\end{array}$ & 48.1 & Moderately & 39 & $<0.1$ & 4 & None & Positive & PPE & Pre/post \\
\hline $81 / \mathrm{M}$ & Metachronous & Cecum & 6.3 & Well & 1.8 & 14.8 & 4 & $\begin{array}{l}\text { Abdominal } \\
\text { wall }\end{array}$ & Negative & $\mathrm{TE}$ & Post \\
\hline $35 / \mathrm{F}$ & Metachronous & $\begin{array}{l}\text { Transverse } \\
\text { colon }\end{array}$ & 24.1 & Well & 10.4 & 14.4 & 2 & None & Negative & $\mathrm{TE}$ & None \\
\hline $65 / \mathrm{F}$ & Synchronous & Rectum & - & Well & 36.7 & NA & 1 & None & Negative & $\mathrm{LAR}+\mathrm{TE}$ & Post \\
\hline
\end{tabular}

F: Female; M: male; PM: peritoneal metastases; PCI: peritoneal carcinoma index; CEA: carcinoembryonic antigen; CA19-9: carbohydrate antigen 19-9; TE: tumor extirpation; PPE: posterior pelvic exenteration; LAR: low anterior resection.

a 5 -year OS rate of $38.4 \%$, which was comparable to that for hepatic or lung metastasis. Furthermore, we showed that it was possible to cure more than a few colorectal PM cases without resorting to the highly invasive treatment of CRS and POIC.

\section{Conflicts of Interest}

The Authors declare no conflicts of interest for this article.

\section{Authors' Contributions}

Gaku Ohira designed the study and wrote the initial draft of the article. All other Authors have contributed to data collection and interpretation, and critically reviewed the article. All Authors approved the final version of the article and agree to be accountable for all aspects of the work in ensuring that questions related to the accuracy or integrity of any part of the work are appropriately investigated and resolved.

\section{References}

1 Franko J, Shi Q, Goldman CD, Pockaj BA, Nelson GD, Goldberg RM, Pitot HC, Grothey A, Alberts SR and Sargent DJ: Treatment of colorectal peritoneal carcinomatosis with systemic chemotherapy: A pooled analysis of north central cancer treatment group phase III trial N9741 and N9841. J Clin Oncol 30(3): 263-267, 2012. PMID: 22162570. DOI: 10.1200/ JCO.2011.37.1039

2 Sugarbaker PH and Ryan DP: Cytoreductive surgery plus hyperthermic perioperative chemotherapy to treat peritoneal metastases from colorectal cancer: Standard of care or an experimental approach? Lancet Oncol 13(8): e362-369, 2012. PMID: 22846841. DOI: 10.1016/S1470-2045(12)70210-3

3 Bushati M, Rovers KP, Sommariva A, Sugarbaker PH, Morris DL, Yonemura Y, Quadros CA, Somashekhar SP, Ceelen W, Dube P, Li Y, Verwaal VJ, Glehen O, Piso P, Spiliotis J, Teo MCC, Gonzales-Moreno S, Cashin PH, Lehmann K, Deraco M,
Moran B and se Hingh IHJT: The current practice of cytoreductive surgery and HIPEC for colorectal peritoneal metastases: Results of a worldwide web-bases survey of the peritoneal surface oncology group international (PSOGI). Eur J Surg Oncol 44(12): 1942-1948, 2018. PMID: 30075978. DOI: 10.1016/j.ejso.2018.07.003

4 Levine EA, Stewart JH, Shen P, Russell GB, Loggie BL and Votanopoulos KI: Intraperitoneal chemotherapy for peritoneal surface malignancy: experience with 1000 patients. J Am Coll Surg 218(4): 573-585, 2014. PMID: 24491244. DOI: 10.1016/ j.jamcollsurg.2013.12.013

5 Konstantinidis IT, Chouliaras K, Levine EA, Lee B and Votanopoulos KI: Frailty correlates with postoperative mortality and major morbidity after cytoreductive surgery with hyperthermic intraperitoneal chemotherapy. Ann Surg Oncol 24(13): 3825-3830, 2017. PMID: 29019118. DOI: 10.1245/s10434-017-6111-0

6 Kobayashi H, Kotake K, Funabashi K, Hase K, Hirata K, Iiai T, Kameoka S, Kanemitsu Y, Maeda K, Murata A, Ohue M, Shirouzu K, Takahashi K, Watanabe T, Yano H, Yatsuoka T, Hashiguchi Y and Sugihara K: Clinical benefit of surgery for stage IV colorectal cancer with synchronous peritoneal metastasis. J Gastroenterol 49(4): 646-654, 2014. PMID: 23793379. DOI: 10.1007/s00535-013-0820-3

7 Ozawa H, Kotake K, Kobayashi H and Sugihara K: Prognostic factors for peritoneal carcinomatosis originating from colorectal cancer: An analysis of 921 patients from a multi-institutional database. Sur Today 44(9): 1643-1650, 2014. PMID: 24077999. DOI: $10.1007 / \mathrm{s} 00595-013-0735-\mathrm{x}$

8 Nagata H, Ishihara S, Hata K, Murono K, Kaneko M, Yasuda K, Otani K, Nishikawa T, Tanaka T, Kiyomatsu T, Kawai K, Nozawa $\mathrm{H}$ and Watanabe T: Survival and prognostic factors for metachronous peritoneal metastasis in patients with colon cancer. Ann Surg Oncol 24(5): 1269-1280, 2017. PMID: 27995451. DOI: 10.1245/s10434-016-5732-z

9 Brierley JD, Gospodarowicz MK and Wittekind C: TNM Classification of Malignant Tumours. UICC International Union Against Cancer, Eighth Edition. New York: Wiley; 2016.

10 Goere D, Malka D, Tzanis D, Gava V, Boige V, Eveno C, Maggiori L, Dumont F, Ducreux M and Elias D: Is there a 
possibility of a cure in patients with colorectal peritoneal carcinomatosis amenable to complete cytoreductive surgery and intraperitoneal chemotherapy? Ann Surg 257(6): 1065-1071, 2013. PMID: 23299520. DOI: 10.1097/SLA.0b013e31827e9289

11 Tsai MS, Su YH, Ho MC, Liang JT, Chen TP, Lai HS and Lee PH: Clinicopathological features and prognosis in resectable synchronous and metachronous colorectal liver metastasis. Ann Surg Oncol 14: 786-794, 2007. PMID: 17103254. DOI: 10.1245/s10434-006-9215-5

12 Kumar R, Price TJ, Beeke C, Jain K, Patel G, Padbury R, Young GP, Order D, Townsend A, Bishnoi S and Karapetis CS: Colorectal cancer survival: An analysis of patients with metastatic disease synchronous and metachronous with the primary tumor. Clin Colorectal Cancer 13(2): 87-93, 2014. PMID: 24373733. DOI: 10.1016/j.clcc.2013.11.008

13 Pelz JO, Chua TC, Esquivel J, Stojadinovic A, Doerfer J, Morris DL, Maeder U, Germer CT and Kerscher AG: Evaluation of best supportive care and systemic chemotherapy as treatment stratified according to the retrospective Peritoneal Surface Disease Severity Score (PSDSS) for peritoneal carcinomatosis of colorectal origin. BMC Cancer 10: 689, 2010. PMID: 21176206. DOI: $10.1186 / 1471-2407-10-689$

14 Bloemendaal AL, Verwaal VJ, van Ruth S, Boot $\mathrm{H}$ and Zoetmulder FA: Conventional surgery and systemic chemotherapy for peritoneal carcinomatosis of colorectal origin: A prospective study. Eur J Surg Oncol 31(10): 1145-1151, 2005. PMID: 16084051. DOI: 10.1016/j.ejso.2005.06.002
15 Klaver YL, Leenders BJ, Creemers GJ, Rutten HJ, Verwaal VJ, Lemmens VE and de Hingh IH: Addition of biological therapies to palliative chemotherapy prolongs survival in patients with peritoneal carcinomatosis of colorectal origin. Am J Clin Oncol 36(2): 157-161, 2013. PMID: 22314003. DOI: 10.1097/ COC.0b013e3182438c55

16 Ihemelandu C: Inflammation-based prognostic scores: utility in prognostication and patient selection for cytoreduction and perioperative intraperitoneal chemotherapy in patients with peritoneal metastasis of colonic origin. Ann Surg Oncol 24(4): 884-889, 2017. PMID: 27896506. DOI: 10.1245/s10434-0165693-2

17 Park IJ, Choi GS and Jun SH: Prognostic value of serum tumor antigen CA19-9 after curative resection of colorectal cancer. Anticancer Res 29(10): 4303-4308, 2009. PMID: 19846991

18 Ohira G, Miyauchi H, Suzuki K, Nishimori T, Tohma T, Narushima K and Matsubara H: Neoadjuvant chemotherapy for advanced colorectal cancer. Jpn J Chemother 40(12): 1626-1628, 2013. PMID: 24393870.

Received March 3, 2020

Revised March 30, 2020

Accepted April 1, 2020 